\title{
Sentir e Inteligir o Anúncio do Evangelho
}

\author{
Feeling and Shouting the Gospel Announcement
}

Sergio Claudio de Sousa

\section{Resumo}

Citações contidas no "Novo Testamento" nos dão o tamanho da complexidade que é sentir e inteligir o Anúncio do Evangelho na pósmodernidade. É inevitável que o encontro do Evangelho com as diferentes culturas dê lugar a diversidade de expressões, porque cada cultura tem seus próprios sinais, símbolos, imagens e linguagem. Mas para que possamos entender a Teologia transpassada pela filosofia do sentir e inteligir de Xavier Zubiri, utilizaremos de recursos teóricos tanto filosóficos quanto teológicos que nos foram fornecidos pelo próprio Zubiri, e posteriormente como este sentir e inteligir o anúncio do Evangelho na história chegou a práxis utilizada por seu discípulo, Ignácio de Ellacuría, este é o objetivo ao qual este trabalho se propõe.

Palavras-chave: Sentir e Inteligir. Evangelho. Zubiri. Práxis.

\begin{abstract}
The quotations contained in the "New Testament" give us the dimension of the complexity that it is to feel and understand the Gospel Announcement in postmodernity. It is inevitable that the encounter of the Gospel with different cultures gives space to a diversity of expressions, because each culture has its own signs, symbols, images and language. But in order for us to understand the Theology pierced by Xavier Zubiri's philosophy of feeling and understanding, we will use theoretical resources both philosophical and theological that were provided to us by Zubiri himself, and later how this feeling and understanding the proclamation of the Gospel in history came to praxis used by his disciple, Ignácio de Ellacuría, this is the purpose of this article.
\end{abstract}

Keywords: Feeling and Intellecting. Gospel. Zubiri. Praxis. 


\section{Introdução}

Jesus ressuscitado manifestando-se aos Onze durante uma refeição "disse-lhes: "Ide por todo o mundo, proclamai o evangelho a toda criatura", (Mc 16,15). A seguir: "Então o Senhor Jesus, depois de lhes ter falado, foi arrebatado aos céus e sentou-se à direita de Deus. Eles saíram para proclamar em toda parte, cooperando com eles o Senhor, e confirmando a Palavra pelos sinais que o acompanhavam" (Mc 16,19-20).

Marcos nos coloca diante de um momento de definição para estes Onze homens, ou seja, Jesus os censura pela incredulidade e a dureza de coração, porque não acreditaram naqueles que o viram ressuscitado, e lhes pede não uma prova imediata ou momentânea de aceitação, como o fizera anteriormente, pois no Evangelho de Mateus temos: "Então Jesus disse aos seus discípulos: "Quem quiser vir atrás de mim negue-se a si mesmo, carregue a sua cruz e siga-me" (Mt 24,14).

Esta aceitação do seguimento era tão radical quanto à nova proposta feita por Jesus que era uma mudança permanente de suas próprias vidas, ide e proclamai o Evangelho a toda criatura, mas como e porque eles o fariam se a alguns momentos antes não acreditavam no mesmo como ressuscitado, qual foi a causa geradora desta mudança na forma de pensar e agir.

\section{Proclamar o Evangelho}

Não devemos perder de vista a proposta feita a eles por Jesus, que é a mudança de vida, esta é a proposição, vão e façam de sua vida um anúncio da "Boa Nova", vivam este anúncio e que todas as criaturas vejam em vocês, nas suas ações, palavras e atitudes, esta "Boa Nova".

É importante citar aqui a mudança de atitude e de vida do Apóstolo Paulo, que teve uma apreensão de realidade como real, Jesus, pois quando o próprio Paulo nos diz: "não que eu já o tenha recebido ou já seja perfeito; prossigo, no entanto, para ver se o alcanço, uma vez que fui alcançado por Jesus Cristo" (F1 3,12), um homem arrebatado completamente pelo Senhor: "já não sou mais eu que vivo, mas é Cristo que vive em mim" (Gl 2,20); e pela sua missão: "ai de mim se não evangelizar!" $(1$ Cor 9,16$)$.

E ainda se deve ter presente que com estes "Onze", iniciou-se esta Evangelização, e que nos chegou através de outros durante os séculos de história que transcorreram entre eles e nós, e que deverá continuar ainda depois de nossa existência. A pergunta que se faz é: estamos preparados para tão grande tarefa? A fim de nos ajudar na apreensão desta realidade da missão de 
proclamar o Evangelho, o Papa Francisco escreveu a Exortação Apostólica Gaudete et Exsultate. No capítulo I, intitulado A chamada à Santidade, temos:

Para um cristão, não é possível imaginar a própria missão na terra, sem a conceber como um caminho de santidade, porque esta é, na verdade, a vontade de Deus: a nossa santificação (1Ts 4,3). Cada santo é uma missão; é um projeto do Pai que visa refletir e encarnar, num momento determinado da história, um aspeto do Evangelho. ${ }^{1}$

\section{Adiante o Santo Padre destaca:}

Poderá porventura o Espírito Santo enviar-nos para cumprir uma missão e, ao mesmo tempo, pedir-nos que fujamos dela ou que evitemos doarnos totalmente para preservarmos a paz interior? Obviamente não; mas, às vezes, somos tentados a relegar para posição secundária a dedicação pastoral e o compromisso no mundo, como se fossem distrações no caminho da santificação e da paz interior. Esquecemo-nos disto: não é que a vida tenha uma missão, mas a vida é uma missão. ${ }^{2}$

Nestes parágrafos, o Papa Francisco diz de nossa missão na terra e o caminho de nossa santificação, mais do que isso, nos identifica com Cristo e que junto de Cristo devemos caminhar na realização deste compromisso, e por fim com uma citação de Zubiri, “(...) A vida é uma missão”, nos coloca sob a proteção do Espírito Santo. Portanto, para que se possa compreender este pequeno trecho da Exortação Apostólica Gaudete et Exsultate do Papa Francisco e o contexto geral do trabalho precisaremos elucidar alguns pontos utilizando-nos do trabalho filosófico e teológico de Xavier Zubiri. ${ }^{3}$

Devemos ressaltar que o desenvolvimento da filosofia Zubiriana é extenso, incluindo-se nesse contexto a teologia, mas neste trabalho utilizaremos uma abordagem especial que são os livros considerados como Trilogia Inteligência Senciente, em que os temas: Inteligência e Realidade, Inteligência e Logos, e Inteligência e Razão, Zubiri nos introduz no universo da apreensão da realidade por meio do sentir e inteligir. A profundidade e a clareza da filosofia de Zubiri nos dão uma base sólida sobre a qual o conhecimento pode

\footnotetext{
${ }^{1}$ GE 19.

${ }^{2}$ GE 27.

3 Xavier Zubiri (1898-1983) foi um filósofo espanhol cujo trabalho se concentrou, fundamentalmente, nos campos da metafísica e da noologia. Foi discípulo de Ortega y Gasset e Heidegger.
} 
ser construído no futuro. A trilogia senciente teve a intenção de registrar as chaves de seu pensamento original.

É importante frisar que este filósofo utilizou-se de outros trabalhos que os seus predecessores filósofos e teólogos elaboraram, e ele também não tem a palavra final, pois como ele mesmo nos diz a realidade deve atualizar-se, e para que tudo faça sentido precisamos utilizar de algumas definições tanto Zubirianas como da própria Pós-Modernidade para compreender melhor o Sentir e Inteligir o anúncio do Evangelho.

\section{Sentir e Inteligir}

Xavier Zubiri realiza seu trabalho filosófico com um impressionante desligamento conceitual, que pode ser um obstáculo para aqueles que os tem como fundamentos filosóficos estabelecidos, aos quais ele os define como conceptivos (conceitos), mas graças a sua intrínseca abstração se tem várias possibilidades de aplicação, ${ }^{4}$ não só nos estudos da metafísica, como também em outros estudos filosóficos e no nosso caso teológico.

Ao querer nos aprofundar nos conceitos metafísicos e querer chegar ao núcleo de sua metafísica, devemos perceber que a mesma gira em torno da realidade. A realidade como fundamento de tudo, como o primário e básico, no qual todos nós nos situamos, a essência como o unitário da coisa, como sistema, que possibilita sua abertura a totalidade da realidade, finalmente, a estrutura dinâmica, que é a essência mesma, "realitas in essendo", dando de si por sua própria realidade, desde a mais sensível reação química até o dar-se de si da história.

Para Zubiri o sentir é: os sentidos têm uma importância muito mais profunda do que de uma simples sensação. Os sentidos, os cinco clássicos, e outros seis definidos por Zubiri são: 1. Visão: a vista me faz sentir a realidade colocando diante de nós seu eidos. 2. Audição: o ouvido me remete à realidade da coisa sonora: inteligir é auscultar. 3. Olfato: o olfato oferece a realidade apreendida como rastro. 4. Gosto: o gosto faz viver o real como possuído ou degustado. 5. Tato (contato-pressão): o tato nos oferece a realidade como nua ou mera apresentação. 6. Sensibilidade labiríntica e vestibular: este sentido apresenta a realidade como algo que tem posição, que está centrado. 7. Calor e 8. Frio: as sensações de calor e de frio levam consigo a apresentação da realidade como temperante. 9. Dor e o Prazer: este sentido nos faz "inteligir" a

\footnotetext{
${ }^{4}$ Disse Ortega "O que é a filosofia", que, desde Kant, a metafísica e a gnosiologia tem por obsessão encontrar um juízo sintético a priori.
} 
realidade como "afetante", 10. Cinestesia (sentido muscular e articular): através dele a realidade é apresentada como algo "até", algo que leva uma direção, uma apresentação direcional e nos faz "inteligir" como tensão dinâmica. 11. Cenestesia ou sensibilidade. Outra observação de Zubiri é que nenhum dos sentidos se sobrepõe aos outros, ou seja, não existe ordem de importância de nenhum modo de apreensão sobre os outros na impressão de realidade.

O inteligir, no livro "Sobre la esencia", é possível detectar uma concepção da unicidade da ação dos sentidos e da inteligência. "A sensibilidade é, com certeza, somente 'sensibilidade-de' o racional, e este, por sua vez, é, somente 'racionalidade-de' a sensibilidade". ${ }^{5}$

$\mathrm{O}$ ato de inteligir não é completo independentemente do ato de sentir, ambos constituem um ato uno, desta forma o filosofo catalão rompe com a filosofia clássica, que afirmava serem dois momentos distintos, ou seja, um de sentir e outro de inteligir.

A intelecção é, pois, constitutiva e estruturalmente senciente em si mesma enquanto intelecção. Reciprocamente, no homem o sentir é constitutiva e estruturalmente intelectivo em si mesmo enquanto sentir. Donde a sensibilidade não ser uma espécie de resíduo "hilético" da consciência como diz Husserl, nem um factum brutum, como a chamam Heidegger e Sartre, mas um momento intrínseco e formal da própria intelecção. ${ }^{6}$

\section{A apreensão de realidade}

Xavier Zubiri vai nos delineando em suas obras como por exemplo: Inteligência e Realidade, Estructura dinámica de la realidad, o que ele entende por apreensão de realidade, desta forma pode-se dizer que:

Intelecção senciente: $\mathrm{O}$ momento de impressão qualifica o ato apreensor como ato de "sentir" e o momento de realidade qualifica-o como um ato de "inteligir", que consiste em apreender algo como real. Sentir e inteligir são dois momentos de algo uno: a apreensão da realidade. A intelecção é senciente, ou seja, aquele que faz a apreensão sente a realidade, e o sentir é intelectivo. $\mathrm{O}$ ato de inteligir não é completo independentemente do ato de sentir. Ambos constituem um ato uno. O que há de ser oposto não é o sentir e o inteligir, mas o inteligir e o puro sentir animal. Há apenas um

${ }^{5}$ ZUBIRI, X., Sobre La essencia, p. 292.

${ }^{6}$ ZUBIRI, X., Inteligência e Realidade, p. 57. 
ato, com dois momentos: o momento senciente é "impressão", o momento intelectivo é "de realidade". Esta unidade (entre intelecção e sensibilidade) não é uma síntese, como seria para Kant, mas é estrutural: o sentir sente a realidade, o inteligir intelige o real impressivamente. $\mathrm{Na}$ concepção de dois atos, temos uma "intelecção do sensível”. Seu objeto primário é o sensível, são os dados dos sentidos. ${ }^{7}$

E esta intelecção do sensível que tem como ato formal o conceber e o julgar, na inteligência senciente, o objeto primário é a realidade apreendida, esta que nos é dada pelos onze sentidos definidos por Zubiri. A esta realidade dada "na" inteligência tem como ato formal e intrínseco a apreensão primordial de realidade.

Desta forma podemos observar que "os Onze" fizeram uma intelecção senciente, ou seja, eles sentiram a realidade que consiste em apreender algo como real, e o que era este real, Jesus; e esta foi a chave para a mudança pessoal destes. Lembremos que no Evangelho de Mc 16,12-19, já citado, os apóstolos não acreditavam em Jesus ressuscitado até o mesmo manifestar-se a eles (os Onze), observemos em Lc 24,36-41:

Enquanto falavam disso, Jesus se apresentou no meio deles e lhes disse: "A paz esteja convosco"! Eles, porém, surpresos e assustados, pensavam em estar vendo um espírito. Ele lhes disse: "Porque estão perturbados? Porque surgem dúvidas em vossos corações? Vede minhas mãos e meus pés: sou eu mesmo! Tocai-me e vede, porque um espírito não tem carne nem ossos como estais vendo que eu tenho". Tendo dito isso mostroulhes as mãos e os pés. Mas como eles, por causa da alegria ainda não acreditavam e continuavam admirados, disse-lhes: "Tendes algo para comer".

Com esta manifestação de Jesus percebemos que:

O sentir não está constituído pela diversidade qualitativa, mas pela unidade de apresentação do real, pela unidade do momento de formalidade. A impressão de realidade é sempre "inespecífica". A formalidade não é uma qualidade a mais, transcende todos os conteúdos, tendo uma "estrutura transcendental". O que é transcendental é o que constitui o objeto formal da inteligência, a realidade presente em impressão. "Trans" não significa "estar além" da apreensão; neste caso a apreensão seria do "transcendente". "Trans" é um caráter interno ao

${ }^{7}$ BELLO, J. S., Deus, experiência do homem em Xavier Zubiri, p. 20-21. 
apreendido, não nos tira dele, mas nos submerge nele. A impressão não é do transcendente, mas "impressão transcendental". O apreendido em impressão de realidade é, enquanto realidade, "mais" que o que é como colorido, sonoro, etc... ${ }^{8}$

Na Exortação Apostólica Pós-Sinodal Verbum Domini do Santo Padre Bento XVI, nos fala sobre A Palavra de Deus na vida e na missão da Igreja que é anunciar ao mundo o "Logos" da esperança, e é onde encontramos um Paulo arrebatado pelo Senhor e uma Igreja missionária:

O Verbo de Deus comunicou-nos a vida divina que transfigura a face da terra, fazendo novas todas as coisas (Ap 21,5). A sua Palavra envolve-nos não só como destinatários da revelação divina, mas também como seus arautos. Ele, o enviado do Pai para cumprir a sua vontade (Jo 5,36-38; 6,38-40; 7,16-18), atrai-nos a Si e envolve-nos na sua vida e missão. Assim o Espírito do Ressuscitado habilita a nossa vida para o anúncio eficaz da Palavra em todo o mundo. É a experiência da primeira comunidade cristã, que via difundir-se a Palavra por meio da pregação e do testemunho (At 6,7). Quero citar aqui particularmente a vida do Apóstolo Paulo, um homem arrebatado completamente pelo Senhor (Fl 3,12), "já não sou eu que vivo, é Cristo que vive em mim" (Gl 2,20) - e pela sua missão: "Ai de mim se não evangelizar!" (1 Cor 9,16), ciente de que em Cristo se revela realmente a salvação de todas as nações, a libertação da escravidão do pecado para entrar na liberdade dos filhos de Deus. ${ }^{9}$

\section{O que vem a ser a atualização em Xavier Zubiri}

Se aos "Onze" e a Paulo, Jesus manifestou-se de formas de apreensão diferentes, como Jesus apresentar-se-á a nós hoje? Afinal quem nos faz esta atualização:

O que está presente na intelecção senciente é a realidade. A este "estar" presente da realidade, Zubiri denomina "atualidade", que não é o caráter de "ato" de algo, no sentido aristotélico (que na terminologia zubiriana chama-se atuidade), mas o caráter de "atual", que alude a uma espécie de presença "física" do real. É o estar presente de algo "desde si mesmo" em algo. O essencial não é a "presentidade", mas o "estar". Intelecção é atualidade, é "estar presente" na intelecção. O real, ao estar inteligido, está em atualidade. A atualidade não é relação nem correlação. A

\footnotetext{
${ }^{8}$ BELLO, J. S., Deus, experiência do homem em Xavier Zubiri, p. 22.

${ }^{9} \mathrm{VD} 91$.
} 
intelecção não é uma relação do inteligente com as coisas inteligidas. A relação é algo que se estabelece entre o inteligente e a coisa já inteligida; a atualidade é o estabelecimento dos relatos, é um tipo de "respectividade". A atualidade funda-se na realidade intelectivamente apreendida; a apreensão intelectiva é atualidade da realidade: A intelecção apreende o real impressivamente e a apreensão das qualidades sensíveis é uma apreensão de qualidades reais. ${ }^{10}$

Temos, portanto, a definição de como se dá esta apreensão de realidade e de como esta se atualiza, mas nos falta ainda alguns elementos para a definição de como "Os onze" fizeram a apreensão de Jesus e do Evangelho e de como nós a fazemos hoje, desta forma precisamos ainda de algumas definições e agora teológicas de Zubiri, sobre religação, posteriormente Deus e Trindade.

\section{A via da "religação"}

Podemos a partir de agora chegar a elaboração de uma síntese da definição da via de religação, em Zubiri, que coloca Deus dentro da nossa constituição pessoal, é a raiz de nosso próprio ser, portanto viver é estar e constituir-se no poder do real, desta forma Deus tem que ser o fundamento deste poder, o poder do real, um fundamento último, possibilitante e impelente: "tem que ser uma realidade suprema, ser uma realidade absoluta não 'frente à' realidade enquanto tal, mas, 'em e por si mesma', uma realidade que seja absolutamente absoluta". ${ }^{11} \mathrm{E}$, dentro de uma dimensão teologal, temos ainda que dizer como este Deus realidade real se apresenta a nós, e de que forma fazemos a sua apreensão como real.

Toda minha realidade (e não só o sentimento ou a vontade ou a inteligência por separado) está envolta por esse poder do real presente em cada coisa. Daí que a religação não seja algo humano como contradistinto do cósmico, senão que é o acontecer da realidade no homem e do homem na realidade. É a manifestação do poder da realidade como ultimidade, possibilitação e impelência. Deus seria justamente o fundamento desse poder, um fundamento, por conseguinte, último, possibilitante e impelente, uma realidade suprema absolutamente absoluta. Como já visto, o homem é, para Zubiri, uma realidade pessoal "cuja vida consiste em fazer física e realmente seu $\mathrm{Eu}[\ldots]$ apoiada no

${ }^{10}$ BELLO, J. S., Deus, experiência do homem em Xavier Zubiri, p. 24.

${ }^{11}$ BELLO, J. S., Deus, experiência do homem em Xavier Zubiri, p. 24. 
poder do real. Só e por este apoio pode a pessoa viver e ser: é o fenômeno da religação". ${ }^{12}$

Podemos dizer que:

A pessoa está constitutivamente e formalmente religada ao poder do real. Deve-se entender a religação não como uma mera vinculação nem um sentimento de dependência, mas a religação como constitutiva e formal ao poder do real como fundamento da vida pessoal de cada ser humano". ${ }^{13}$

\section{A ação criadora de Deus na teologia filosófica de Xavier Zubiri}

Zubiri em sua obra, Natureza, História, Deus, percorre uma linha de pensamento que se pode dizer:

Devemos destacar que a criação tem dois momentos distintos. Sem entrarmos no estudo da descrição criadora de Deus feita em Genesis, podemos dizer que: Em primeiro lugar, o fim do ato criador é a realidade enquanto tal, a realidade outra de Deus, e em segundo lugar, esta alteridade não tem nenhum ponto de partida. Ou seja, o ato criador significa a produção das coisas a partir do nada, isto é, significa que não há um sujeito prévio, o que nos leva a concluir que é uma realidade que poderia não ter sido, e que começou a ser, não por causalidade mecânica, mas por ação espiritual e livre da vontade de Deus, desta forma evitamos o pensamento panteísta. ${ }^{14}$

Poderíamos ainda destacar um pensamento sobre a criação de São Tomás de Aquino, referindo-se unicamente ao Deus Criador, onde a criação constituise como sendo o ato pelo qual Aquele que é, isto é, o Ato Puro de Existir, produz a totalidade dos atos finitos de existir.

O autor explica que isto é um nihilum de realidade e não um nihilum de ser: o ser é uma atualidade ulterior do real, porque a realidade finita antes de ser é real e porque Deus é a suprema realidade que está além do ser. No Novo Testamento a ideia de criação está assente na própria estrutura trinitária de Deus (1Cor 8,6; Col 1,15-20): é a palavra proferida de algo que é precisamente a verdade real de Deus e que é a realidade própria do

12 TOMÉ, A. P., A relação entre Deus e o Homem em Xavier Zubiri, p. 42.

${ }^{13}$ BELLO, J. S., Deus, experiência do homem em Xavier Zubiri, p. 24.

${ }^{14}$ DIMAS, S. F. R., A ação criadora de Deus na teologia filosófica de Xavier Zubiri, p. 24. 
Filho. É a criação das coisas do Pai, pelo Filho, no Espírito Santo. O Pai é a fonte absoluta de toda a realidade, mas aquilo que esta só pode ser, em sua verdade, é o que constitui a realidade mesma do Filho, que é a Verdade. No Espírito Santo dá-se a atualização da identidade daquilo que é a verdade com o que é realidade. Deus é uma realidade absolutamente absoluta e, por conseguinte, é plenamente Seu. ${ }^{15}$ Nada pode ser absolutamente seu se não for uma essência aberta que possui em si mesma intelecção e vontade. ${ }^{16}$

Portanto Zubiri nos diz que: "é no Espírito Santo que se dá a atualização da identidade daquilo que é a verdade com que é a realidade", ${ }^{17}$ o mesmo Espírito Santo que nós cristãos ocidentais temos como "O grande desconhecido", como definiu Royo Marín ${ }^{18}$ em sua obra.

Na economia da revelação divina, existe uma palavra própria do Pai, uma palavra própria do Filho, porém não há nenhuma palavra, ensinamento ou mensagem próprios do Espírito Santo. Ele não fala por si, mas inspira e faz falar os homens segundo as palavras do Pai e do Filho. Ele é sempre um dom para a missão de criar e libertar, ou seja, missão de dar e manter a vida. Assim, a práxis cristã é componente necessário do acolhimento do Espírito Santo e consequentemente do encontro autêntico com Cristo: "Se vivemos pelo Espírito, procedamos também de acordo com o Espírito" (Gl 5,25). E se o Espírito é espírito de liberdade, sabemos que a liberdade se realiza no serviço voluntário aos outros especialmente os mais necessitados, na defesa da vida [...]. Esta práxis (ver I. Ellacuría) exigida para que a Igreja se mostre hoje dirigida pelo Espírito Santo, vai na direção de impulsionar a formação de comunidades. ${ }^{19}$

Ressaltamos que "novas situações, tanto eclesiais como sociais, econômicas, políticas e culturais, reclamam hoje, com uma força toda particular, a ação dos fiéis leigos. Se o desinteresse foi sempre inaceitável, o tempo presente torna-o ainda mais culpável. Não é lícito a ninguém ficar inativo". ${ }^{20}$

\footnotetext{
${ }^{15}$ ZUBIRI, X., El Problema Teologal del Hombre, p. 156-172.

${ }^{16}$ DIMAS, S. F. R., A ação criadora de Deus na teologia filosófica de Xavier Zubiri, p. 491.

${ }^{17}$ DIMAS, S. F. R., A ação criadora de Deus na teologia filosófica de Xavier Zubiri, p. 491.

${ }^{18}$ Antonio Royo Marín O. P. (1913 - 2005) foi um religioso da Ordem dos Dominicanos, e teólogo espanhol, autor de inúmeras obras de alcance internacional. ROYO MARIN, A., O Grande Desconhecido.

${ }^{19}$ RATZINGER, J., O sal da Terra, p. 18.

${ }^{20}$ CL 3.
} 
Mas foi o Patriarca da Igreja de Antioquia, Ignácios Hazim, que nos deu o sentido mais profundo da pneumatologia cristã quando ele diz:

Sem Ele (o Espírito Santo) Deus fica distante; Cristo permanece no passado; o Evangelho é letra morta; a Igreja, uma simples organização; a autoridade, um domínio; a missão propaganda; o culto, uma simples recordação e a prática cristã, uma moral de escravos. Mas, no Espírito Santo, o Cosmo é elevado e geme nas dores do parto do Reino, o homem luta contra a carne. Então: Jesus ressuscitado está aqui; o Evangelho é potência de vida; a Igreja significa comunhão trinitária; a autoridade é um serviço libertador; a missão um Pentecostes; a liturgia é memorial e antecipação e a ação humana é divinizada. ${ }^{21}$

Ainda nesta caminhada filosófica e teológica, passamos da apreensão do sentir e inteligir Jesus e o Evangelho, e a ação do Espírito Santo que nos atualiza e que através de sua força nos impulsiona na direção da formação das comunidades e de agir com efetiva participação na história, e é nesse contexto que podemos entender "Os Onze" e a Práxis Ignácio de Ellacuría. ${ }^{22}$

Entender que Deus não pode ser concebido com um objeto, algo que se encontra à minha frente, e sobre o qual eu possa dizer o que é, mas uma realidade que é "si e por si", e por isso mesmo posso tê-la como fundamento.

Este posicionamento de Zubiri e ao qual Ellacuría seguiu deve-se em grande parte a influência que como discípulo Zubiri teve de José Ortega y Gasset que entende o conhecimento filosófico como uma reflexão sobre a própria vida, como um diálogo com o entorno, com base na circunstância concreta em que cada homem se encontra imerso.

\footnotetext{
${ }^{21}$ Discurso realizado na IV Assembleia do Conselho Ecumênico das Igrejas, realizada em Upsala em 1968 apud CIPOLINI, P. C., O Espírito Santo promotor de contínua purificação e renovação da Igreja.

${ }^{22}$ Ignacio Ellacuría, (nasceu em Portugalete, na Província de Vizcaya, Espanha, a 9 de novembro de 1930. Em 1947, ingressou na Companhia de Jesus e em 1949 foi transferido para El Salvador, onde após obter o doutorado atuaria, com algumas interrupções, até a sua morte em 1989. Em 1961 iniciou o doutorado, concluído em 1965, na Universidade Complutense de Madri, sob a direção de Xavier Zubiri, onde escreveu uma tese sobre "A principialidade da essência". Seu pensamento filosófico tem dois momentos: 1. a superação da "filosofia idealista"; 2 . a defesa da filosofia da libertação, que serve como fundamento para uma ética libertadora e ilumina a práxis política. A principal contribuição de Ellacuría no plano teórico é a proposta de uma filosofia e de uma teologia "posidealista", que teriam como método a historização dos conceitos e como princípio inspirador a práxis histórica. A premissa dessa proposta é a crença de que a historicidade forma parte da estrutura do conhecimento filosófico e teológico.
} 
O instrumento dessa reflexão é a razão, mas não a razão abstrata que a ciência utiliza, e, sim, a "razão vital" ou "razão histórica". Para o autor, o homem não pode se colocar no lugar de espectador da própria vida. Ao contrário, o protagonista do drama não está fora dele, nem antes dele: é a representação do drama. A identidade do homem tem como conteúdo seu próprio projeto, ou seja, o papel que decide representar no drama de sua existência, drama que, por sua vez, consiste e se esgota no argumento. "O argumento e somente o argumento é a substância da vida...". 23

Para o filosofo espanhol José Ortega y Gasset a afirmação de que "o homem é o homem e a sua circunstância", considerou o homem como o sujeito de sua própria realidade em um mundo em movimento e transformação, inserido em um determinado momento histórico. Desta forma a educação é essencial para poder proporcionar a conscientização de sua circunstância neste momento histórico, relacionando-se com ela, de modo a superá-la, segundo Ortega "se não a salvo, não me salvo eu também".

Percebemos que não foi somente Xavier Zubiri a ser influenciado por José Ortega y Gasset, este deu novos contornos para o pensamento de Ortega, mas foi Ignácio de Ellacuría que tendo Zubiri como seu orientador e todo o suporte filosófico deste, aprofunda não somente o pensamento do homem não ser expectador de sua própria vida e sim o ator principal, mas também na prática.

Outra obra de Zubiri a "Estructura dinámica de la realidad" situa a metafísica zubiriana com grande importância na atualidade. A história está como diz Zubiri nesta obra, montada sobre o conceito de "possibilidade". A história é uma atualização de possibilidades. A história refere-se à forma de realidade como princípio de possibilidades de realização do homem, recai, portanto, sobre "sucessos", pois, para Zubiri, sucesso é a "atualização de possibilidades". ${ }^{24}$

E nesta obra culmina em uma consideração sobre os dinamismos da sociedade e da história, que para o filosofo basco entram em pleno direito em sua metafísica da realidade. Neste contexto Zubiri mesmo, introduz a tese de que a realidade inteira do mundo é constitutivamente histórica, pois é o dinamismo próprio da história que afeta a realidade enquanto que realidade.

Como ela não se converte a realidade em uma imensa substancia nas quais se dissolveram todas as demais realidades, senão que simplesmente se

${ }^{23}$ GASSET, J. O., Rebelião das Massas, p. 121.

${ }^{24}$ ZUBIRI, X., Estructura dinâmica de La realidad, p. 272. 
assinala que os dinamismos próprios da história estão em respectividade com o resto das realidades do mundo. ${ }^{25}$

\section{A Práxis em Ellacuría}

A práxis de Ellacuría, no proclamar o Evangelho, vem do modo de como as considerações cosmológicas sobre os dinamismos da matéria e da vida estão constitutivamente vinculados com o histórico, e a "realidade histórica". Desta forma chegará a converter-se em objeto de considerações filosófica própria de Ellacuría. Para este se a unidade transcendental das distintas formas e modos de realidade culmina na história, e se a totalidade do real pode ser entendida como "realidade histórica", esta realidade histórica, é a que constitui o objeto próprio da filosofia. Em sua principal obra intitulada Filosofia de la Realidad Histórica, Ellacuría conclui que a realidade histórica integralmente considerada tem um caráter de práxis.

A partir deste conceito, a práxis integra todos os dinamismos da realidade histórica: naturais e humanos. Isto significa que a práxis é um fazer da realidade histórica que envolve de maneira estrutural todos os dinamismos humanos da natureza. A realidade histórica, para Ellacuría, é o espaço onde ocorrem não somente as mais altas formas de realidade, mas também é o campo aberto das máximas possibilidades do real. Isto não significa que a história esteja acabada, mas se constrói através de um processo de possibilitação e capacitação, ou seja, tarefa de uma práxis histórica: "somente o homem 'realiza' formalmente aquilo que faz, e realiza realizando-se, e é neste âmbito da realização que se deve situar a práxis". O autor continua, entretanto, com a seguinte ressalva: "Senão tão somente aquele fazer que é um fazer real da realidade, um fazer que vai além do fazer natural, porque a história, sendo sempre fato, é sempre mais que fato, e este "mais" é o novum, que o homem acrescenta à natureza, a partir dela, sobre ela". Nesta perspectiva, a história não é tanto um factum, mas, sobretudo, um faciendum. A verdade da realidade histórica não é somente o já feito, isto é, uma parte da realidade. É importante perceber o que se está fazendo e o que está por fazer e tomar consciência, individual e socialmente, do que está por fazer. ${ }^{26}$

Ellacuría após o desenvolvimento filosófico da práxis que integra todos os dinamismos da realidade histórica, naturais e humanas, como citado, utiliza-

${ }^{25}$ ZUBIRI, X., Estructura dinâmica de La realidad, p. 272.

${ }^{26}$ ELLACURÍA, I., Filosofía de la realidad histórica, p. 594. 
se desta para elaborar a filosofia da libertação, que na América central e do sul se expandiu à teologia, transformando-se assim na busca da construção de um mundo novo, em um horizonte utópico e escatológico.

Ellacuría tem seu trabalho filosófico implantado dentro das concepções das lutas dos trabalhadores, dos pobres, das classes menos favorecida, dos camponeses, desta forma é quase que imediato a correlação de seu trabalho filosófico que se estendeu para a práxis, entendida como transformação de realidade, com a filosofia e práxis marxista, o que não parece ser claro e evidente, pois o mesmo nascido em Portugalete, Espanha, em 1930, e com parte de sua formação acadêmica na Espanha, tendo feito sua pós-graduação (doutorado), com Xavier Zubiri, aluno e mestre, ambos espanhóis e com idades diferentes mas que viveram a experiência da apreensão senciente de realidade da destruição da cidade de Guernica, pelo General Franco, destruição ao qual deve-se ressaltar não estar ligada ao marxismo e sim ao movimento anarquista, este movimento sim tinha - "e tem" - em seu horizonte utópico, "os mesmos objetivos" apresentados pelo jesuíta.

Ignácio de Ellacuría tem presente a realidade porque ela se expressa em todos os lugares e não do mesmo modo.

A verdade sobre a realidade não é o que foi feito, isto é só uma parte da realidade. Se não voltarmos ao que está sendo feito e ao que está por fazer, perdemos a verdade da realidade. É necessário fazer a verdade, a qual não supõe, primeiramente, executar, realizar o que já se sabe, mas fazer aquela realidade que em um confronto entre práxis e teoria se mostra como verdadeira, [...] a realidade e a verdade devem se fazer e se descobrir [...] devem se fazer e se descobrir na complexidade coletiva e sucessiva da história da humanidade. ${ }^{27}$

Este caminho seguido por Ellacuría em El Salvador e outros em toda a América Latina, nas décadas finais do século XX, levou em sua esteira ao desenvolvimento da Teologia da Libertação, teologia esta que tem uma mensagem de ação, baseado no método do Ver, Julgar e Agir, ação esta que partia de uma aproximação do conceito marxista, utilizado por Ellacuría.

Deve-se ressaltar que o método citado, Ver, Julgar e Agir, método este utilizado na Teologia da Libertação, é um desenvolvimento prático da teoria Zubiriana.

No livro do Cardeal Arns, "O Evangelho: Incomoda? Inquieta? Interessa?”, sobre o Sínodo da Evangelização realizado em Roma em 1974,

${ }^{27}$ ELLACURÍA, I., Filosofía de la realidad histórica, p. 599. 
pelo Papa Paulo VI, Sínodo este que teve como objeto principal de discussão o da "Evangelização no mundo contemporâneo", a pergunta ao qual deveria se achar uma resposta era: Como fazer com que a Pessoa e a riqueza da mensagem de Cristo sejam aceitas pelos homens de hoje? Pergunta esta que é o centro das preocupações de toda a Igreja Apostólica. Porque hoje, "a Igreja toda quer assumir a responsabilidade de evangelizar". ${ }^{28}$

Com décadas de separação entre o início desta teologia e o Papa Francisco, que viveu outro tipo de teologia daquela definida na Argentina como teologia do Povo, tem outra forma de argumentação para levarmos a frente o anúncio do Evangelho, tomemos como base o discurso do Papa Francisco na Audiência com os participantes da Plenária do Pontifício Conselho para a Promoção da Nova Evangelização, realizada na sala Clementina do Palácio Apostólico em 14 de outubro de 2013, onde o Santo Padre sintetiza que: "a nova evangelização se faz com gestos e atitudes antes ainda do que com palavras, é necessário dar testemunho de vida", ${ }^{29}$ o que frisamos no início deste trabalho.

Desta forma o Papa Francisco resumiu seu discurso em três pontos essenciais: o primado do testemunho; a urgência de ir ao encontro; e o projeto pastoral centrado no essencial. Ele destacou que a nova evangelização é despertar no coração e na mente do outro a vida da fé. E nesse processo, o testemunho é indispensável. "Aquilo de que precisamos, especialmente nestes tempos, são testemunhos credíveis que com a vida e com a palavra tornam visível o Evangelho, despertam a atração por Jesus Cristo, pela beleza de Deus". ${ }^{30}$

Se cada batizado é "cristóforo", isto é portador de Cristo, como diziam os antigos padres. Desta forma quem encontrou Cristo, como a Samaritana no poço, não pode reter para si esta experiência, mas sente o desejo de partilhá-la, para levar outros a Jesus (Jo 4). ${ }^{31}$

Desta forma será que todos que encontramos percebem na nossa vida o calor da fé, e vê na nossa face à alegria de ter encontrado Cristo? Porque,

A Alegria do Evangelho enche o coração e a vida inteira daqueles que se encontram com Jesus. Quantos se deixam salvar por Ele são libertados

\footnotetext{
${ }^{28}$ ARNS, P. E., O Evangelho, Introdução.

${ }^{29}$ FRANCISCO, PP., Discurso do Papa Francisco na Audiência com os participantes da Plenária do Pontifício Conselho para a Promoção da Nova Evangelização.

${ }^{30}$ FRANCISCO, PP., Discurso do Papa Francisco na Audiência com os participantes da Plenária do Pontifício Conselho para a Promoção da Nova Evangelização.

${ }^{31}$ EG 1.
} 
do pecado, da tristeza, do vazio interior, do isolamento. Com Jesus Cristo, renasce sem cessar a alegria. ${ }^{32}$

Temos, portanto um caminho a percorrer até chegarmos ao que "os Onze" e Paulo apreenderam de Cristo e à diferença de apreensão em Ellacuría. Este partiu da história, pensando que mudando a história através de sistemas políticos (que levaram às armas), levaria este homem à plenitude da história, enquanto que Jesus partiu do homem e da verdade, para que este homem fizesse a história, e encontrassem nesta a presença de Deus, pois ele se revela na história, pois não há história sem o homem.

Em Jo 8,31-32 temos: "Dizia então Jesus aos judeus que tinham acreditado nele: 'Se permanecerdes em minha palavra sereis verdadeiramente meus discípulos, conhecereis a verdade, e a verdade vos libertará", disse-lhe ainda Jesus em Jo 6,7: "Sou eu o caminho, a verdade e a vida. Ninguém vai ao Pai senão por mim. Se me conhecêsseis, conheceríeis também meu Pai. Desde agora, vós o conheceis e o vedes" (Jo 14,6-7). Jesus não apenas dizia a verdade, ele é a verdade. Verdade significa algo que é absoluto, que existe, que é real. Ele é real, sempre existiu e sempre vai existir. Não existe falsidade nenhuma em Jesus. Jesus é a verdade que nos liberta do poder do pecado $\left(\underline{J_{0}} 8,36\right)$.

\section{Conclusão}

Através do desenvolvimento filosófico e teológico de Zubiri e em especial de Ignácio de Ellacuría, percebemos a necessidade de sermos nós a fazer história, e agirmos, e passar a ver todas as demais ações humanas como provenientes desta história, assim podemos entender as artes, entre elas as pinturas e suas significações, a música, literatura e todas as formas de expressões sociais entre elas também a política. Mas existe um problema de fundo não com as sociedades e suas formas de expressões nem com a teoria metafísica de Zubiri, e também não com a teologia, mas sim com o homem da pós-modernidade que faz a ponte entre o Sagrado e o mundo atual, ou seja, aqueles que aprenderam a decifrar os registros que o Sagrado inscreveu no ser humano, pois os mesmos não conseguem exprimir no mundo pós-moderno com a velocidade que se exige o anúncio do Evangelho.

Precisamos entender que não há duas histórias: uma sagrada e outra profana:

${ }^{32}$ EG 1. 
Há apenas uma história e nela colaboram Deus e o homem. Mas como falar então de salvação que o Evangelho nos anuncia nessa única história? Como não abandonar o real? A primeira coisa é estar na história, encarregar-se da realidade. Aqui, ser e estar se unificam como já vimos. E então, Ellacuría fala de transcender $n a$ história, não $d a$ história. A transcendência e, portanto, a salvação não é algo que acontece fora da história, mas na história. Há um aprofundamento no que acontece e aí se encontra o dom de Deus, o dom da salvação. ${ }^{33}$

Conforme Zubiri cabe a cada um de nós apreendermos as palavras que tornam visível o Evangelho, que despertam a atração por Jesus Cristo, e pela Beleza de Deus, Nas palavras de Zubiri, ele "não está na frente de mim, mas sim que acontece em mim. Está presente religando-me ao poder do real".

Cada coisa real integra, na sua realidade, a realidade de Deus. O que significa que toda a coisa real, especialmente a pessoa humana, inclui formalmente, no âmbito do seu dinamismo, a dinamicidade da pessoa divina. Por conseguinte, sendo certo que o homem é o artífice do seu ser, é igualmente verdade que não o é totalmente porque é realidade e dinamicidade na realidade e na dinamicidade de Deus. ${ }^{34}$

\section{Referências bibliográficas}

A BÍBLIA: Novo Testamento. São Paulo: Paulinas, 2015.

ARNS, P. E. O Evangelho: Incomoda? Inquieta? Interessa? São Paulo: Edições Loyola, 1975.

BELLO, J. S. Deus, experiência do homem em Xavier Zubiri. Rio de Janeiro, 2018. 108p. Dissertação. Faculdade de Filosofia, Pontifícia Universidade Católica do Rio de Janeiro. Disponível em: < https://www.maxwell.vrac.pucrio.br/6464/6464_3.PDF>. Acesso em: 22 nov. 2018.

BENTO XVI, PP. Exortação Apostólica Verbum Domini. Sobre A Palavra de Deus na vida e na missão da Igreja. São Paulo: Paulinas, 2018.

CASTELLON MARTÌN, J. J. Ellacuría y la filosofia de la práxis. Huelva: Hergué Editorial, 2003.

${ }^{33}$ HURTADO LOPES, J. M., Sobre teologia e outras coisas.

${ }^{34}$ TEIXEIRA, J.A.P., O acesso do homem a Deus em Xavier Zubiri, p. 12.

PqTeo, Rio de Janeiro, v. 3, n. 5, p. 190-208, jan./jun. 2020206 
CIPOLINI, P. C. O Espírito Santo promotor de contínua purificação e renovação da Igreja. REVELETEO, v. 1, n. 2, ago./dez. 2007. Disponível em: $<$ https://revistas.pucsp.br/reveleteo/article/view/6754/4885>. Acesso em: 15 nov. 2018. DOI: 10.23925/2177-952X.2007v0i2p\%p

DIMAS, S. F. R. A ação criadora de Deus na teologia filosófica de Xavier Zubiri. Cauriensia, v. 10, p. 489-505, jan./dez. 2015. Disponível em: $<$ http://dx.medra.org/10.17398/1886-4945.10.489>. Acesso em: 20 nov. 2018.

ELLACURÍA, I. Filosofia de La Realidad Histórica. San Salvador: UCA Editores, 2007.

FRANCISCO, PP. Discurso na Audiência com os participantes da Plenária do Pontifício Conselho para a Promoção da Nova Evangelização, realizada na sala Clementina do Palácio Apostólico em 14 de outubro de 2013. Disponível em: $<$ https://noticias.cancaonova.com/especiais/pontificado/francisco/discurso-dopapa-ao-pontificio-conselho-para-a-promocao-da-nova-evangelizacao/> . Acesso em: 18 de nov. 2018.

FRANCISCO, PP. Exortação Apostólica Evangelii Gaudium. Sobre Anúncio do Evangelho no mundo Atual. São Paulo: Paulus / Loyola, 2013.

FRANCISCO, PP. Exortação Apostólica Gaudete et Exsultate. Sobre o Chamado a Santidade no Mundo Atual. São Paulo: Paulus, 2018.

GASSET, J. O. Rebelião das Massas. Disponível em: $<$ http://livrandante.com.br/jose-ortega-y-gasset-a-rebeliao-das-massas/>. Acesso em: 15 out. 2018.

HURTADO LOPES, J. M. Sobre teologia e outras coisas: coerência radical de Ignacio Ellacuría, S.J. Ameríndia, 13 jan. 2018. Disponível em: $<$ http://www.ihu.unisinos.br/188-noticias/noticias-2018/575472-sobreteologia-e-outras-coisas-coerencia-radical-de-ignacio-ellacuria-sj>. Acesso em: 22 nov. 2018.

JOÃO PAULO II, PP. Exortação Apostólica Christifideles Laici. Sobre a vocação e missão dos leigos na Igreja e no Mundo. São Paulo: Paulinas, 2018.

RATZINGER, J. O sal da terra: o cristianismo e a Igreja Católica no século XXI. Rio de Janeiro: Imago, 1997.

ROYO MARIN, A. O Grande Desconhecido: O Espírito Santo e seus dons. Campinas, SP: Ecclesiae, 2017. 
TEIXEIRA, J. A. P. O acesso do homem a Deus em Xavier Zubiri. Disponivel em:

$<$ https://repositorio.ucp.pt/bitstream/10400.14/18509/1/V03002-149191.pdf $>$. Acesso em: 15 nov. 2018.

TOMÉ, A. P. A relação entre Deus e o Homem em Xavier Zubiri. Porto Alegre, 2007. 106p. Dissertação. Faculdade de Filosofia e Ciências Humanas. Pontifícia Universidade Católica do Rio Grande do Sul. Disponível em: $<$ http://www.dominiopublico.gov.br/pesquisa/DetalheObraForm.do?select_ac tion $=\&$ co_obra $=94367>$. Acesso em: 22 nov. 2018.

ZUBIRI, X. El Problema Teologal del hombre: Dios, religión, cristianismo. Madri: Aliança Editorial / Fundación Xavier Zubiri, 2015.

ZUBIRI, X. Estructura dinámica de la realidad. Madri: Alianza Editorial / Fundación Xavier Zubiri, 1995.

ZUBIRI, X. Inteligência e Realidade. São Paulo: É Realizações, 2011.

ZUBIRI, X. Inteligência e Logos. São Paulo. É Realizações, 2011.

ZUBIRI, X. Inteligência e Razão. São Paulo. É realizações, 2011.

ZUBIRI, X. Natureza, História, Deus. São Paulo: É realizações, 2010.

ZUBIRI, X. Sobre La Essencia. Madri: Alianza Editorial / Fundaciòn Xavier Zubiri, 2018.

Sergio Claudio de Sousa Mestre em Teologia pela Pontifícia Universidade Católica de São Paulo São Paulo / SP - Brasil E-mail: sc.sousa057@gmail;com

Recebido em: $12 / 02 / 19$

Aprovado em: 28/01/20 